\title{
Development of optimal management strategies for sustainable development of port clusters in the Russian Far East
}

\author{
Marina Moiseeva ${ }^{1,{ }^{*}}$, Marina Melnikova ${ }^{1}$, Anna Ogneva ${ }^{1}$ \\ ${ }^{1}$ Maritime State University named after Admiral G.I. Nevelskoy, Verhneportovaya street, 50-A, \\ 690059,Vladivostok, Russia
}

\begin{abstract}
The paper is intended to identify areas of management application for the formation of sustainable development of cities and seaports. Special attention is paid to the sea ports of the Russian Far East. At the same time, a special study was carried out, which allowed to distinguish four special clusters. Each of these clusters requires a special application of the forces of all levels of management to develop appropriate strategies. The role of labour potential in the implementation of the proposed strategies was also noted.
\end{abstract}

\section{Introduction}

The purpose of this study is to find and structure the factors that influence the sustainable development of the sea trade ports of Russia, especially in the Far East (FE), which are often the city-forming enterprises.

The special importance of achieving this goal lies in the fact that the ports and port infrastructure of the Russian Federation are developing with the active formation of market mechanisms. According to the experts of the far Eastern Department of state Maritime surveillance, the accumulation and use of private capital in seaports is now reflected in the structure of the owners of port hydro technical structures (PHTS) (Fig. 1).

As can be seen from Fig. 1, although according to the results of studies in the Far East district, facilities owned by the state $-65 \%$ (or $67 \%$, taking into account the involved in civil turnover of the property of the Ministry of defense), but, nevertheless, owned by private owners was already $32 \%$ of the PHTS. The opinion was made according to 2013 (when the organization carried out such analysis), at the moment even more PHTS is in hands of private owners. This applies not only to the Far East, but also Novorossiysk (NSTP) and St. Petersburg. All major players in the industry are now investing in the construction of new lines and the reconstruction of terminals. So, the owners of NSTP are: Novoport Holding Ltd. (joint venture company «Transneft» and «Summa Group») - 50,1\% of the shares; the Federal property management Agency - $20 \%$ of the shares; close corporation «Transneft - Service» $-10,5 \%$ of the shares; $14.4 \%$ of the shares are in free float on the Moscow and London stock exchanges. Since February 11, 2008 the owner of public

\footnotetext{
${ }^{*}$ Corresponding author: mari25.62@mail.ru
} 
corporation «Sea port of St. Petersburg» is the Dutch company Universal Cargo Logistics Holding B. V. (UCLH).

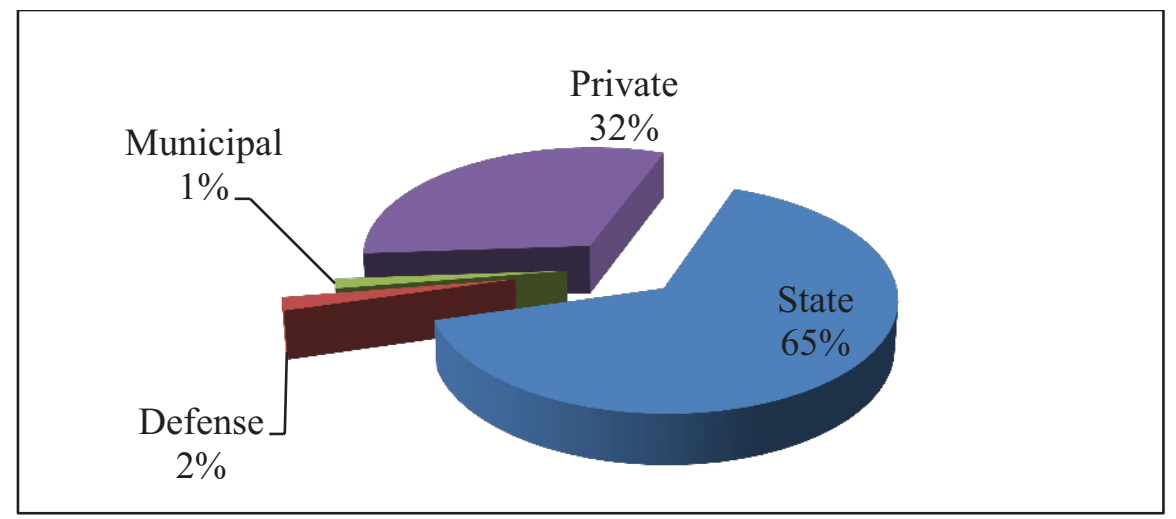

Fig. 1. The ownership structure of PHTS in the FE of the Russian Federation as for 2013 (compiled by [3]).

Another important factor influencing seaports is the stability and growth of cargo turnover, which means the creation of opportunities for sustainable development of the cities in which these ports are located [1].

Such large cities of the Far East as Vladivostok, Magadan, Vanino, Petropavlovsk Kamchatsky, etc. strongly depend from the ports which are in their territory as a rule, ports are the largest taxpayers both Federal, and in local Treasury.

Thus, a thorough study of the competitive environment that has emerged and is still increasing in the area of services provided by seaports; as well as the prospects for the growth of cargo turnover can give an idea of the possibilities of managing these processes for the development of port cities.

\section{Materials and methods}

The methodological basis of the study is a comprehensive analysis, a systematic approach and General scientific methods: analysis and synthesis; induction and deduction; comparison. The research used methods of grouping, sociological research (primary and secondary), expert assessments and statistical processing of information. Been evaluated also the theory of the formation of strategies in management [2].

On the coast of the Far East of Russia for more than 5,6 thousand nautical miles there are 22 sea trade and 10 fish sea ports. The largest of them are: in the Primorsky Krai - Vostochny port, Nakhodka, Vladivostok, Posyet and Zarubino, in the Khabarovsk territory is the port of Vanino and De-Kastri, in Saha Akmola region - Kholmsk, Korsakov, and Uglegorsk, in Magadan oblast Magadan, and Petropavlovsk-Kamchatsky in Kamchatka Krai. More than $95 \%$ of all cargo flows of the Far East pass through these ports. Hence-their role and importance in the economy of the region and the country as a whole. For example, the largest transport hubs (along with port railway stations, highways, and other elements of transport and logistics infrastructure) of the Far East - Vladivostok, Nakhodka and Vanino - are formed precisely on the basis and around the largest ports - Vladivostok, Nakhodka and Vanino. We can say that they, in turn, are the core of the so-called "port clusters"of the same name.

On the other hand, from the point of view of transport features of the organization of work of ports and volumes of processed goods, all of them can be (with a certain degree of conditionality) divided into four large groups [3]. 
The first group includes the ports of Vostochny, Vladivostok, Nakhodka and Posyet (Vladivostok port cluster), as well as Vanino (Vanino, or Vanino-Sovgavan cluster), which are connected with the transport system of the country by railways. In 2015, these five ports handled 77.6\% (132.7 million tons) of all cargo passing through the Far Eastern basin. The second group includes ports (Sakhalin cluster) connected by pipelines with Sakhalin offshore fields: Prigorodnoye, De-Kastri, and serving the needs of one company. Their turnover amounted to the same, 2015, about 15.5\% (26.5 million tons) of cargo turnover of the ports of the basin. The third group consists of 14 small ports in terms of port operations, which are located in areas where there are no land communications, and which currently provide transshipment of goods to ensure the livelihoods of settlements in which they are located, with the nearest neighborhoods. Their capacity is used today by an average of 10$50 \%$, and there are no serious prerequisites for increasing their cargo base and cargo turnover growth yet. And finally, the fourth group, in our opinion, can be attributed only to a single port (emerging so-called Zarubino cluster) - the port of Zarubino in Primorye, which has a railway and auto-mobile approaches, good location, very good opportunities for development (however, requiring billions of dollars in investment) and almost fully loaded power port. Especially important and promising for the region and the whole country are the prospects for the development of this port in connection with the creation of the free port of Vladivostok and the development of its cargo base, which is formed largely in northeast China.

Features of differentiation of clusters are given in table 1.

Table 1. Features of differentiation of port clusters FE.

\begin{tabular}{|l|l|}
\hline \multicolumn{1}{|c|}{ Port clusters of FE } & \multicolumn{1}{|c|}{ Feature } \\
\hline \multicolumn{1}{|c|}{1} & \multicolumn{1}{|c|}{2} \\
\hline $\begin{array}{l}\text { Cluster Vladivostok (Vostochny, Vladivos- } \\
\text { tok, Nakhodka and Posyet), cluster Vanino } \\
\text { (Vanino) }\end{array}$ & $\begin{array}{l}\text { Connected with the transport system of the } \\
\text { country by railways }\end{array}$ \\
\hline $\begin{array}{l}\text { Sakhalin cluster 1 (Prigorodnoye, De- } \\
\text { Kastri) }\end{array}$ & Serves needs of the gas field \\
\hline $\begin{array}{l}\text { Sakhalin cluster 2 (14 ports of Sakhalin with } \\
\text { no land communications) }\end{array}$ & $\begin{array}{l}\text { Serves the local needs of the settlements of } \\
\text { Sakhalin }\end{array}$ \\
\hline Zarubinsky cluster (Zarubino in Primorye) & $\begin{array}{l}\text { A lightly loaded production capacity. Has } \\
\text { prospects for development of cargo base in } \\
\text { northeast China }\end{array}$ \\
\hline
\end{tabular}

The allocation of clusters (table 1) enables the management of territories of different levels to develop different behavior strategies.

To date, the Maritime Board under the government of the Russian Federation has approved a Strategy for the development of the Maritime port infrastructure of Russia until 2030 with promising cargo turnover. But, according to experts, when creating such documents of a programmatic nature, it should be borne in mind that the economy, trade and commodity movement are by nature mobile development environments that seek to find the most convenient routes. Therefore, not only the current cargo base forecasts, but also the development of ports and their infrastructure depends on the choice of specific routes of cargo and goods movement by shippers. This approach takes into account both the possibilities of cargo base development and the fact that ports can influence its formation [4]. However, such a task is not set in the strategy. But for sustainable development, it is necessary to create an active position that is most suitable for the country's chosen direction for modernization and innovative approaches.

\section{Results}


The conducted researches connected with the necessity of differentiation of sea trade ports on the example of FE have shown the presence of four almost complete formed port clusters.

Such formalization helps to make the right strategic decisions both to private owners, owners of PHTS, and to the state, that is, to change all possible levels and forms [5].

Table 2 shows the expected strategies that create attractive services for the consumers of seaports, increase their profitability and growth opportunities, and ultimately lead to the sustainable development of the cities in which they are located.

Table 2. The management strategy for the port cluster FE.

\begin{tabular}{|l|l|}
\hline \multicolumn{1}{|c|}{ Port clusters of FE } & \multicolumn{1}{|c|}{ Management strategy } \\
\hline \multicolumn{1}{|c|}{1} & \multicolumn{1}{|c|}{2} \\
\hline $\begin{array}{l}\text { Cluster Vladivostok (Vostochny, Vladivos- } \\
\text { tok, Nakhodka and Posyet), cluster Vanino } \\
\text { (Vanino) }\end{array}$ & $\begin{array}{l}\text { The presence of the largest cargo turnover } \\
\text { requires special attention to the development } \\
\text { of logistics infrastructure }\end{array}$ \\
\hline $\begin{array}{l}\text { Sakhalin cluster 1 (Prigorodnoye, De- } \\
\text { Kastri) }\end{array}$ & $\begin{array}{l}\text { Need to develop in accordance with gas } \\
\text { projects }\end{array}$ \\
\hline $\begin{array}{l}\text { Sakhalin cluster 2 (14 ports of Sakhalin with } \\
\text { no land communications) }\end{array}$ & $\begin{array}{l}\text { Does not require large investments in the } \\
\text { absence of prospects for the development of } \\
\text { the region }\end{array}$ \\
\hline Zarubinsky cluster (Zarubino in Primorye) & $\begin{array}{l}\text { Require the infusion of billions of dollars in } \\
\text { investment }\end{array}$ \\
\hline
\end{tabular}

As is known, the factors of production are land, capital, entrepreneurial ability, information and labor. All these factors can be ensured in the implementation of the proposed strategies. But the work of these factors is almost exclusively the prerogative of the state strategic policy, when the state can act as a motivator for the consolidation of labor resources in important areas, an arbitrator between a private employer and an employee and, finally, an employer [6].

Sustainable urban development of FE clearly linked to business development, including port. At the same time, the opportunities of this business are directly related to the availability of appropriate labor potential. The analysis of the labor potential of the far East indicates unfavorable migration-outflow of population to the Central regions.

For creation of favorable conditions of formation of labor potential of $\mathrm{FE}$ it is possible to offer the following actions [7]:

1. Creation of the hi-tech productions in the territory of edge focused on high quality and, as a consequence, on competitiveness of products. We must not forget about the development and modernization of existing industrial enterprises belonging to the traditional branch of industry and transport.

2. The development of social infrastructure as a condition for improving the quality of life of the population, including economically active, and to keep the population requires not only high quality social services, but also their outpouring in comparison with other regions of the country.

3. To improve the conformity of the structure of the regional market of educational services and the quality of training of future employees to different segments of the labor market, and more precisely to the expectations of the employer and the needs of the labor force within the region; and to promote social responsibility of business in relation to existing and potential employees.

Thus, the implementation of the proposed strategies requires the efforts of the state to develop the employment potential of the Far East, and the subsequent development of port business contributes to this. 
The obtained results correspond to the theory of formation of the strategy of investment depending on the strength of competition in the markets of sellers and buyers, and the technology of choice required in the situation of the strategy of system integration activities.

The theoretical analysis of the development of competition in the markets of buyers and sellers in seaports suggests the presence of oligopsony and oligopoly, respectively. Therefore, in accordance with the theory and the appropriate technology to choose the strategy reflected in figure 2, for the best development of port clusters, it is necessary to take advantage of system integration, which means "...management for the purpose of fuller use by each subject of the exclusive competitive advantages for the benefit of all subjects, receiving synergetic effect"

\section{Conclusions}

Formation of the most exact strategic behavior is one of technologies of successful development of port business. The cost of mistakes in this area of management is extremely high. This is especially true in the Russian Far East, where all efforts to implement projects are doubled, but the value of achievements is also double.

In the field of port business today, the role of the state is still very large, although it tends to decrease and the emergence of competition. Therefore, only active joint actions of the state and private business can give the highest effect.

Differentiation of ports into clusters reduces the high degree of uncertainty of business behavior, highlighting the most priority areas of investment, and also demonstrates the state the necessary spheres of influence. All this forms a platform for effective management. The result of effective management is the sustainable development of the seaports and the cities in which they are located.

\section{References}

1. S. Zatepyakin, Plenary reports of the 11th international scientific conference «Problems of transport of the Far East», 22-25 (2015)

2. M. Moiseeva, A. Fisenko, Plenary reports of the 11 th international scientific conference «Problems of transport of the Far East», 112-114 (2015)

3. A. Ogneva, N. Porshkevich, Ekonomika I Sotsium 7 (26), 237-241 (2016)

4. Transportation Group FESCO, Reports, http://www.fesco.ru/investor/documents/ reports/ (2018)

5. A. Fisenko, E. Kuleshova, M. Moiseyeva, Transportnoye Delo Russii 3(124), 100-102 (2016)

6. R. Fatkhutdinov, Upravlenie konkurentosposobnostyu organizatsii (Eksmo, Moskva, 2005)

7. R. Fatkhutdinov, Strategicheskiy marketing (Piter, Sankt-Peterburg, 2008) 